\section{Teaching: A Women-Only Profession?}

\section{SARAH-EVE FARQUHAR}

\section{Abstract:}

The latest statistics on teacher gender show a continuing downward trend in the participation of male teachers across secondary, primary and early childhood education. The trend is more pronounced in the primary than in the secondary sector, while early childhood education, which has never had a significant proportion of men, seems over the past five years to be losing more than it is attracting. This paper identifies key reasons for the feminisation of teaching, focusing on the early years of education (0-8 years). The main advantages of having male teachers on the staffare presented. Teacher gender seems to matter most for children's learning during the early years of education. It is argued that the growing gender gap here should be regarded as a problem of serious professional and political concern.

W

hile driving on a State Highway you may happen to spot large billboards advertising beer, with the caption of "What it means to be a man". One poster for example, shows a boy watching a man shave his face, an activity that typically only males engage in. Another poster shows a man and child fishing with rods, an activity which is seen in society to be what males rather than females prefer to do for recreation. We are reminded daily that sex-role stereotyping is probably as strong as ever, especially for boys and men (Phillips, 1987; "The Trouble with Men," 1996). We are also reminded that there are strong group differences between males and females, hampering success over the past two to three decades in efforts to change structural inequalities between women and men in employment and in the home (Cox, 1987; Sayers \& Tremaine, 1994).

In 1996 a study was carried out on male early childhood teachers. Twenty male childcare and kindergarten teachers were interviewed along with a female colleague of each of the men (Farquhar, 1997). It was found that female teachers, even those who viewed themselves as

\section{Sarah-Eve Farquhar}

being fairly androgynous or "butch", considered that male teachers were good to have on the staff for providing a masculine caring role model for children and for the different perspective and interests they brought to the teaching team.

One argument against targeting men for teaching is that gender is irrelevant, because women are quite capable of performing typically male activities with children (such as kicking a rugby ball). However, without male teachers, children will continue to observe that teaching is a female occupation, and women teachers will not be practising what they expect of children in being non-sexist and inclusive of social differences. A staff consisting of both male and female teachers is better able to support equal opportunities for both boys and girls, and to create environments that respect every individual (Coulter \& McNay, 1993; Jensen, 1996).

\section{The Statistics}

The data presented in Table 1 show a consistent downward trend in male teacher employment in the primary and secondary school sectors. Since 1971 the proportion of male to female teachers has dropped 17.1 percent in the state primary school sector and 11.4 percent in the secondary school sector. In 1997 one-fifth of primary school teachers were male, and just less than half of all secondary teachers were male. In early childhood education, only two in every one hundred teachers were male. The already very low percentage of male childcare teachers halved between 1992 and 1997. The chief explanation for the reduction in the ratio of male to female childcare teachers is the effect of publicity surrounding two high profile sex abuse cases in childcare centres, causing some men to leave the field and some to enter kindergarten rather than childcare teaching.

\section{Reasons for the Dearth of Male Teachers}

There are at least four inter-related reasons why men today are less likely to choose the teaching of young children as an occupation, and why male teachers are difficult to retain. Two contemporary reasons are: fear that male teachers might molest children, and support for women's employment opportunities. Two traditional reasons are: cultural beliefs about the roles of men and women, and the status and conditions of teaching (including pay). 
Table 1 Percentage of male staff (full time teacher equivalent) in state schools and early childhood services ${ }^{1}$

\begin{tabular}{lrrr}
\hline & 1971 & 1992 & 1997 \\
\hline Primary & 37.8 & 24.4 & 20.7 \\
Secondary & 58.8 & 51.5 & 47.4 \\
Kindergarten & & 0.7 & 0.9 \\
Licensed childcare & & 2.6 & 1.3 \\
\hline
\end{tabular}

1. Data on teacher gender in kindergartens and childcare prior to 1992 are not available.

\section{Sex abuse}

In New Zealand, two major cases of child sex abuse (at a Christchurch and a Wellington childcare centre) have been used as an argument against the appointment of male staff in early childhood services (Farquhar, 1997; Jensen, 1996). Similar arguments have been advanced in the United Kingdom. Since initial allegations of the sexual abuse of Christchurch children by Peter Ellis surfaced, in November 1991, the media have given the case considerable attention. The court case was the longest-running one for sexual abuse in New Zealand's history, and attempts to have the 10-year conviction overturned at the Court of Appeal and at the Privy Council have kept the case in the media spotlight. Most recently, the 20/20 television feature on the Ellis case has raised serious doubts about his guilt. If Peter Ellis were to be pardoned, it would be interesting to consider the impact this may have on attitudes towards men working in childcare and whether men would then be more willing to enter early childhood teaching.

A number of less well-publicised cases of child sex abuse by primary and secondary school teachers may also be having some effect on male employment in these sectors, although no evidence is yet available. Overseas research has indicated that the sex abuse issue does affect men's interactions with children in elementary and junior secondary classrooms (Allan, 1993; Coulter \& McNay, 1993; Skelton, 1994). A New Zealand Human Rights Commission consultant who has held workshops with representatives from primary and secondary schools comments, "... a lot of people feel that it's really sad that men can't pick up a little kid in the playground any more, because they are putting themselves at risk" (Hotere, 1996, p. 3).
Jensen (1996) argues that it is wrong that men's sexuality should be focused on in education. The little-publicised conviction of a woman for sexual violation of a child in 1996, the convictions of two women childcare workers for physical assaults on children in 1996, and the police charging of a woman caregiver with the death of a 17-month girl by physical assault in 1997 suggest double standards exist towards abuse and abusers ("Crêche Staff Found Guilty," 1995; Wellwood, 1996).

Since the early 1980s men who wanted to work in early childhood education tended to be warmly welcomed and even sought after, because a "token" male teacher was viewed as a way of helping to break down stereotyping in children's play and behaviour. However male teachers now report that they are looked upon with suspicion by parents, and are often discriminated against when applying for jobs, due to the sex abuse issue (Farquhar, 1997).

Education Minister Wyatt Creech has stated that while the "highly publicised sexual abuse cases had generated 'dreadful PR' for male teachers ... he doubted the Government could do much to aid the situation" (EDUVAC, 1997, p. 1). In other words, this issue has been put in the "too hard basket", politically. The New Zealand Educational Institute, which represents early childhood and primary teachers, does not recognise that sexual abuse fears are a key reason why men are turning away from teaching (Tocker, 1997). Instead the union argues that men have always had to be more careful than women in their interactions with children, and that the main problems faced by teachers are not accusations of sexual abuse but wages and professional status.

National early childhood organisations, including the New Zealand Educational Institute, developed protocols and guidelines for early childhood teachers to reduce the possibility of being accused of child sex abuse. These various guidelines were developed in response to the sex abuse cases and serve to further remind male teachers that they cannot be trusted because of their gender (Farquhar, 1997). For example, one male teacher quoted in Farquhar's study said, "dressing and undressing (children) never used to be a problem but now we are teaching children that it is a problem when a man teacher is there" (p. 33). The sex abuse issue is a major one affecting male teacher employment and retention. It is also an important issue affecting how women teachers work with children (Duncan, 1997), but there is no evidence that it is being used to keep women out of teaching. 
Women, and not men, are seen to be disadvantaged

In early childhood education, a major difficulty in increasing the participation rate of men is that women as a group are disadvantaged within the wider labour market. This has meant that the government, teachers' unions and training institutions have not felt able to mount an effective challenge to the trend towards feminisation (EDUVAC, 1997; "Lack of male primary teachers," 1997). Many schools are now staffed only by women teachers, and even employ female caretakers (EDUVAC, 1997, p. 1). In the early childhood sector, the lack of male participation is rarely discussed, for fear this could threaten women's jobs (Clyde, 1995).

Equal employment opportunity (EEO) policy does not seem to be an effective mechanism for supporting or improving the representation of men in teaching (Farquhar, 1997). All early childhood services and schools are required by the Ministry of Education to have an EEO policy, but it is left up to individual employers whether they regard men as a special target group, because men are not one of the designated groups under current EEO legislation (National Radio, 1997).

\section{Social beliefs about the roles of men and women}

Young children are viewed in society as women's responsibility. For example, it is accepted without debate that kindergarten teachers are called "girls" and that men are not given visibility within early childhood teaching (Duncan \& Rowe, 1997). Hoffman and Teyber (1985) argue that until there is more equal participation in the care of children by men and women, real change in traditional sex roles will not occur. However, this is a chicken and egg problem of what comes first - more men becoming involved in work with young children despite social pressures not to, or changes in social attitudes to allow men into the female domain.

Australian research by Grbich (1992) shows that when fathers become the primary caregivers of their children they are marginalised in society. They are called names such as "poofs" and "queers". Women and breadwinner males avoid talking with them and ostracise them. Like the fathers in Grbich's study, New Zealand male early childhood teachers are given a hard time by peers and others. Van Deursen's (1989) survey of 17 male childcare teachers in New Zealand shows that the "flak" they received because they were men was very discouraging. Naish (1995) interviewed six male early childhood teachers and found that they were not encouraged at high school or supported at Teachers'
Colleges to be early childhood teachers. Naish argues that the view that caring for children is not a suitable job for men is still prevalent in society. Farquhar (1997) reports that male kindergarten and childcare teachers experience less support than female teachers from their families and peers for their decision to work with young children. For example, one female teacher said that people were pleased with her choice of occupation because it was a good one for a girl. A male teacher said that his friends teased him and called him a "girl" and a "child molester". Male teachers felt they had to prove they were not gay to reduce this type of suspicion. While female teachers can be outwardly lesbian, male teachers are more likely to face accusations of child abuse unless they are married and have children.

\section{Working conditions}

There is a well-known saying in education: the older the child the higher the pay and social status. Hence there are more male teachers in primary teaching than in early childhood, and more males in secondary than in primary teaching. The low wages, low social status and limited career structure within the early childhood field are inter-related factors which mean that early childhood teaching is not considered by most men to be a possible job option (Farquhar, 1995). Traditionally men are the breadwinners, and so the level of pay tends to be more important to men than it is to women (Jensen, 1996). In the early childhood sector, male teachers are more likely than their female colleagues to be the main income earners in their household (Farquhar, 1997).

Primary teachers have recently achieved pay parity with secondary teachers, and one outcome could be an increase in the number of male teachers within primary schools, according to the president of the Principals' Federation, Nola Hambleton (EDUVAC, 1997). However, if the ratio of men to women in secondary teaching continues to decline, and drops below 40 percent, then the changing status of secondary teaching through its alignment with primary teaching may prove to be a stronger explanation for male flight from teaching than pay alone.

\section{Advantages in having a balance of male and female teachers}

Huttunen's (1992) study of children's experiences and memories of their early childhood programme indicates that female teachers cannot take the place of male teachers, and that male teachers are important, particularly for the quality of boys' early childhood experience. To quote Huttunen: 
All in all boys were more critical about early childhood programs than girls. Girls remembered their caregivers' personalities with more love than boys. Maybe one reason for that is that programs are planned and run mostly by women and it is easier for girls to understand a woman's world, respect her personality and agree with her style on guiding activities. (p. 13)

Research indicates that boys are more likely to admire and copy the behaviour of their male teachers rather than their female teachers (Gold \& Reis, 1982). Male teachers are more likely than female teachers to respect and cater for boys' interests and needs, such as for more boisterous play (Farquhar, 1997; Jensen, 1996). A major reason for having male teachers is that through their example boys observe that it is acceptable for men to participate in the care of children (Farquhar, 1997).

Male teachers can assist both boys and girls to develop their ideas of masculinity, and this is something that women cannot do (Morgan, 1997; King, 1994). In settings where male teachers are employed, girls are affected more than boys in their choice of activities, and all children engage more with activities involving construction and movement (Jensen, 1996). Male teachers also mean an increase in dialogue between children and adults and an increase in social games (Jensen, 1996). There is no evidence that male teachers are better or worse in their work performance than female teachers. There seems to be little difference in the work that female and male teachers actually do (Robinson, 1988). However, they tend to be different in how they care, interact, and play with children (Jensen, 1996). The evidence thus suggests that children benefit most from a balance of female and male teachers.

A popular argument in support of male teachers is that they are important for children who do not have a father or who are brought up mainly by their mother (Editorial, 1997a; Langley, Christchurch College of Education liaison officer quoted by Webber, 1997; Editorial, 1997b). Male teachers are also believed to be useful for providing boys and girls whose "fathers" are constantly changing with a stable positive male figure (Jensen, 1996). Exposure to positive male role models during the early years is regarded as somewhat of a panacea to social problems such as higher rates of youth suicide, a lowering of boys' academic achievement levels in comparison to girls', and a rise in school bullying and truancy amongst boys (Martin, 1996; Morgan, 1997). Social learning theory supports popular beliefs about the importance of the "male" influence on the development of children's behaviour and attitudes (Holmes, 1996; Lamb, 1981).

The entry of men into early childhood teaching can demonstrate within society that men are capable of taking responsibility for children. After the release of Farquhar's (1997) report on male early childhood teachers, a number of letters were received from fathers about difficulty in achieving custody and access to their children. The writers believed that greater acceptance of the importance of men in teaching could help society to be more accepting of the fathers' role in parenting. A letter to the editor of the Evening Standard newspaper by Tomlinson (1997) of the Family Rights group stated:

We of Family Rights believe the removal of bias against fathers in the Family Court needs to be addressed to allow the positive parenting input of both father and mother. As fathers wanting this, our pleadings are ignored. Hopefully Dr Farquhar's report will not be.

Meyerhoff (1994) argues that women often unconsciously discourage men from being present and involved with children. Research findings show that mothers and female teachers can become more aware of their own sexism through having contact with male teachers, and that after working with a male teacher women prefer to have a man on the staff (Farquhar, 1997; Skeen, Robinson \& Coleman, 1986). A man on the teaching staff provides a signal to fathers that men are welcome in the early childhood centre setting or school, and that men can play a part in children's care and education (Farquhar, 1997). Unfortunately, men tend to draw back from contact and involvement with young children because of the mistaken belief that they are less capable than women due to their gender (Meyerhoff, 1994). Buck (1985) suggests that the lack of men in early childhood teaching and the low level of fathers' involvement in child-rearing are inter-related problems, and takes the view that an increase in the numbers of male teachers should help to increase fathers' participation in their children's care.

\section{Conclusion}

This paper started by identifying a downward trend in the employment of male teachers within the compulsory school sector and in childcare. In kindergarten the situation has remained fairly static, reflecting the fact that no significant efforts have been made in the past five years to recruit men into the profession. Contemporary and traditional reasons for teaching becoming, and in the case of early childhood being, a 
women's profession are identified and discussed. There are numerous advantages in having male teachers and evidence suggests that a balance of male and female teachers is desirable for children.

Male flight from teaching should not be ignored by the teaching profession, nor should it be simply passed off by policy-makers and administrators as a problem that is too difficult and complex to address. Vigorous public debate is needed about the value of male teachers, and the reasons for the decline in their numbers. Positive publicity about male teachers is vital to help reverse the damage that has been done by high profile sex abuse cases over this decade. The teaching profession needs to work on developing a more positive public image of teachers and teaching, rather than focussing on enduring problems of pay and status which are more likely to dissuade men from becoming teachers. Policy makers and administrators should be proactive in joining with employers and training providers to put in place a national plan for getting and retaining more male teachers. Finally, teacher unions could be doing much more to support male teachers and to address specific issues and difficulties experienced by them as group.

\section{References}

Allan, J. (1993). Male elementary teachers' experiences and perspectives. In C. Williams (Ed.), Doing women's work: Men in non-traditional occupations (pp. 112-127). California: Sage.

Buck, L. Z. (1985). Emerging roles of males as child caregivers: Fathers and early childhood teachers. (ERIC document ED264946).

Child Care Employee Project. (1989). The national child care staffing study. Who cares? Child care teachers and the quality of care in America. Oakland, LA: Child Care Employee Project.

Clyde, M. (1995, September). Is early childhood a man's world? Paper presented at the 6th Early Childhood Convention, Auckland.

Coulter, R. P., \& McNay, M. (1993). Exploring men's experiences as elementary school teachers. Canadian Journal of Education, 18(4), 398413.

Cox, S. (1987). Public and private worlds: Women in contemporary New Zealand. Wellington: Allen \& Unwin.

Crêche staff found guilty. (1995, April 13). Evening Post, p. 3

Duncan, J. (1997, December). Not for men alone: Kindergarten staff protection policies and sexual abuse. Paper presented at NZARE Conference, Auckland.
Duncan, J., \& Rowe, L. (1997). Don't be too polite girls, don't be too polite: Kindergarten teachers and employment contracts. New Zealand Annual Review of Education, 6, 157-178.

Editorial. (1997, January 28). Abuse allegations. The Otago Daily Times, p. 8.

Editorial. (1997, January 29). Society suffering as males run scared of abuse accusations. Daily News.

Farquhar, S-E. (1995). Qualifications, gender and income: Inter-related issues in the early education sector. New Zealand Annual Review of Education, 4, 39-55.

Farquhar, S-E. (1997). A few good men or a few too many? A study of male teachers. Research report. Palmerston North: Massey University.

Gold, D. \& Reis, M. (1982). Male teacher effects on young children: A theoretical and empirical consideration. Sex Roles, 8(5), 493-513.

Grbich, C. (1992). Societal response to familial role change in Australia: Marginalisation or social change? Journal of Comparative Family Studies, 23(1), 79-94.

Growing gender gap in primary school teaching. (1997). EDUVAC: The Education Weekly, 8(311), p. 1.

Hoffman, C. D., \& Teyber, E. C. (1985). Naturalistic observations of sex differences in adult involvement with girls and boys of different ages. Merrill-Palmer Quarterly, 31(1), 93-97.

Holmes, R. (1996). Teacher gender equity principles by example: A case for male early childhood professionals. Workshop notes. FKA Multicultural Resource Centre, Melbourne.

Hotere, A. (1996, October 4). Disturbing tales of sexual harassment in schools. New Zealand Educational Review.

Huttunen, E. (1992, August). Children's experiences in early childhood programs. Paper presented at the ISSBD Biannual Conference, Seville.

Jensen, J. J. (1996). Men as workers in childcare services. European Commission discussion paper. European Commission Network.

King, J. R. (1994). Uncommon caring: Primary males and implicit judgments. (ERIC document ED375086).

Lack of male primary teachers. (1997, August 2). The Press, p. 3

Lamb, M. E. (1981). The role of the father in child development. New York: Wiley.

Martin, Y. (1996, January 20). School scheme to target anti-social pupils. Sunday Star-Times, p. A2. 
Meyerhoff, M. K. (1994). Of baseball and babies: Are you unconsciously discouraging father involvement in infant care? Young Children, 49(4), 17-19.

Morgan, G. (1997, January 20). The social threat we face if boys continue to drift in education. Christchurch Press, p. 9.

Naish, J. F. (1995). Men in early childhood: The Uncle Remus story. Unpublished research project, University of Otago, Dunedin.

National Radio. (1997, January 21). Interview with Elspeth Maxwell of the Ministry of Education, on Checkpoint.

Phillips, J. (1987). A man's country? The image of the pakeha male. Auckland: Penguin.

Robinson, B. E. (1988). Vanishing breed: Men in child care programs. Young Children, 43(6), 54-58.

Sayers, J. \& Tremaine, M. (1994). The vision and the reality: Equal employment opportunities in the New Zealand workplace. Palmerston North: Dunmore Press.

Skeen, P., Robinson, B. E., \& Coleman, M. (1986). Gender role attitudes of professional female educators toward men in early childhood education. Psychological Reports, 559, 723-730.

Skelton, C. (1994). Sex, male teachers and young children. Gender and Education, 6(1), 87-93.

The trouble with men. (1996, September 28). The Economist, p. 17.

Tocker, A. (1997, January 28). Men scared off teaching by sex claims Report. The Dominion.

Tomlinson, C. (1997, February 14). Letters to the Editor: Father role models needed. Evening Standard, Palmerston North

Van Deursen, B. (1989). A survey of men in childcare in New Zealand. Unpublished research paper, Massey University, Palmerston North.

Webber, L. (1997, A pril 25). Primary school puzzle: Men shy away from teaching. Christchurch Star, p. 1.

Wellwood, E. (1996, April 17). Women who prey on boys. Evening Post, p. 23.

\section{Postscript}

After being acquitted of charges of sexual abuse, primary school teacher John Edgar warned men not to consider teaching as a career, and advised men already in teaching to get out. His comments on the risks of being a male teacher received nation-wide media attention on April 29,1998 . His case is further evidence that men teachers are more vulnerable than women to this type of allegation, and confirms that the sex abuse issue now needs to be seen as a potential causal factor in the declining proportion of male teachers in New Zealand.

\section{The author}

Sarah Farquhar's research interests are in the areas of educational quality, teacher education, and children's learning. Her past experience includes: national student representative on the Kindergarten Teachers' Association, head kindergarten teacher, and College of Education lecturer. Sarah is currently a lecturer in education at Massey University, and a mother of a two young children. She welcomes correspondence on male participation in teaching. Email: S.E.Farquhar@massey.ac.nz. 